\title{
Program Pengembangan Ide UMKM Waroeng Kopi Singgah
}

\author{
Septianti, Fitriatus Solikah, \& Sholehatul Mardiyah \\ Universitas Ma'arif Hasyim Latif, Indonesia \\ Universitas Ma'arif Hasyim Latif, Indonesia \\ Universitas Ma'arif Hasyim Latif, Indonesia \\ septianti@dosen.umaha.ac.id \\ fitriatus_solikah@student.umaha.ac.id \\ sholehatul_mardiyah@student.umaha.ac.id
}

Abstract: Waroeng Kopi Singgah is a coffee shop that focuses
on selling coffee on Pilang Street No.200, Wonoayu Sidoarjo. The sales location is strategic, but during this pandemic period it has decreased so that there is a lack of interest in visitors to come to the coffee shop to stop by. The purpose of implementing this program is to increase knowledge about making suitable product brands, knowledge about how to market through digital marketing, an increase in products with various variants, and an increase in turnover after selling through various online media. To achieve the expected goal, a series of activities were carried out using the PAR (Particitory action research) approach method, with various stages in its implementation, namely 1). Planning, this stage is carried out offline observation and identification of problems that are being experienced by the owner of the Singgah coffee shop. 2). Implementation, carrying out a series of activities from rebranding to marketing through digital marketing, and 3). Evaluation, assessment of the work program implemented. The result of the implementation of this activity is the presence of a new logo reflecting the stopover coffee shop, the existence of two coffee variants, namely arabica and robusta. In addition, there is promotion by making digital marketing through online media such as 
Instagram and shopee. Through a series of activities, it is hoped that there will be an increase in turnover and wider product recognition through online media.

Keyword: idea development, umkm, coffee

\section{Pendahuluan}

Waroeng kopi singgah merupakan UMKM yang berfokus dalam penjualan kopi, yang didirikan oleh Muhammad Malik Ibrahim pada tahun 2018. Lokasi penjualan terletak di jalan raya Pilang no.200, Wonoayu, Sidoarjo, lokasinya cukup strategis karena dekat dengan jalan raya. Awal mula berdirinya warung kopi ini berawal saat pemilik melakukan perjalanan ke Lombok dan berhenti pada suatu warung kopi yang ada dipinggir jalan. Sehingga akhirnya pemilik memberi nama warung kopinya yaitu "Singgah" yang memiliki arti berhenti sebentar untuk disuatu tempat saat melakukan perjalan atau biasa dikatakan 'mampir'. Dari situ pemilik memiliki suatu harapan bahwa warung kopi ini bisa didatangi oleh para pengunjung yang datang dari luar maupun dalam Sidoarjo, yang akan saling bertukar kebudayaan.

Seperti diketahui UMKM ini merupakan usaha kecil ekonomi produktif yang berdiri sendiri atau suatu badan usaha yang bukan anak usaha ataupun cabang (Sarfiah, Atmaja, and Verawati 2019). Sehingga usaha ini masih belum dikenal dan belum banyak para pengunjung yang mendatangi Waroeng kopi singgah. Selain itu warung kopi sudah 
memiliki brand akan tetapi belum mencerminkan ciri khas dari warung kopi tersebut. Sementara walaupun sudah memiliki produk kopi yang siap dijual pemilik belum melakukan pemasaran secara digital marketing hingga belum banyak masyakat yang mengenal produknya.

Pada saat ini waroeng kopi singgah mengalami suatu permasalahan mulai berkurangnya pengunjung yang diakibatkan adanya penyebaran Covid-19 yang makin meningkat di wilayah Sidoarjo. Setelah kami melakukan survei kami melihat adanya permasalahan-permasalah yang dialami pemilik. Oleh karena itu, dalam program pengabdian masyarakat kami mencoba mengembangkan ide kreatif untuk memperkenalkan waroeng kopi singgah lebih luas baik di luar maupun dalam Sidoarjo. Sehingga nantinya dapat berkontribusi untuk membantu perekonomian dan mengembangkan penjualan secara digital marketing.

\section{Metode}

Pada program dan kegiatan KKNT-KK yang diselenggarakan oleh LPPM UMAHA, kelompok kami menggunakan metode pendekatan PAR (Particitory action research), yang dikembangkan oleh seorang psikolog yang bernama Kurt Lewin. PAR merupakan suatu pendekatan yang dilakukan denga tujuan untuk pembelajaran dan mengatasi permasalahan yang dibutuhkan oleh masyarakat, disertai memberikan suatu ilmu pengetahuan, dan adanya suatu perubahan sosial 
masyarakat. Selain itu pendekatan PAR bertujuan membangun kesadaran masyarakat, mengubah cara pandang, dan menciptakan suatu perubahan nilai sosial di masyarakat. (Afandi 2018).

Dalam metode ini memiliki empat prinsip yang saling berelasi yaitu partisipasi, aksi, triagulasi, dan fleksibel. Untuk melakukan tahap dalam PAR mengharuskan dilaksanakan separtisipasi mungkin, selain itu melibatkan siapa saja yang nantinya akan mengubah kondisi lebih baik. Secara umum metode ini terbagi menjadi dua tipe, pertama eksplanatif yaitu mengajak masyarakat untuk menganalisis kebutuhan, permasalahan dan solusi sebelum merencanakan aksi. Pada proker ini akan mengunakan PAR tematik menganalisis program aksi transformatif yang sudah berjalan, sebagai alat untuk mengevaluasi dan monitoring. Proker kedua kami akan menggunakan PAR tematik untuk menganalisis UMKM Waroeng kopi Singgah yang sudah berjalan yang nantinya akan dilakukan transformasi dan melakukan pengamatan halhal yang diperlukan untuk mengembangkan ide usaha UMKM Waroeng kopi Singgah.

Dalam proses pelaksanaan kegiatan ini akan dilakukan selama 1 bulan dari tanggal 23 November samapi dengan 23 Desember 2020. Adapun tahapan yang dilakukan untuk melaksanakan proker KKN-KK kelompok kami sebagai berikut: 
1. Perencanaan, Pada tahapan ini kelompok kami melakukan observasi langsung Woerung kopi Singgah. Observasi dilakukan dengan beberapa orang dengan tetap menjaga protokol kesehatan. Melalui observasi kami melakukan identifikasi dari potensi dan menganalisis permasalahan yang sedang dialami oleh pemilik dan hal-hal yang perlu ditingkatkan dalam upaya mengembangkan ide usaha bagi UMKM waroeng kopi Singgah.

Setelah melakukan observasi dan menentukan permalahan yang sedang terjadi dilakukan tahapan perencanaan dengan melihat kondisi lingkungan, menganalisis resiko, mencari kontak untuk memperoleh perizinan, penyusunan strategi yang meliputi penyusunan rencana perjalanan, mempersiapkan fisik, dan penyiapkan akomodasi yang cukup untuk mengatasi segala permasalahan di lapangan.

2. Pelaksanaan, Pada tahapan pelaksanaan dilakukan yaitu merebranding logo yang ada pada UMKM yang dirasa masih belum mencerminkan citra dari waroeng Singgah. Sementara itu hal lain dilakukan yaitu, membuat pemasaran melalui media sosial dari Instagram dan Shopee. Setelah pembuatan rebranding dan pemasaran melalui media online dilakukan penyusunan aksi agar UMKM waroeng Singgah dapat mulai dikenal oleh masyarakat Indonesia. 
3. Evaluasi, Tahapan selanjutnya yaitu evaluasi, pada tahapan ini dilakukan penilaian terhadap kinerja yang dilakukan melalui metode PAR. Selain itu dilakukan penyusunan laporan dan mengevaluasi setiap proker. Melalui tahapan perencanaan dan pelaksanaan kegiatan yang dilakukan masih memiliki kekurangan dan perlu adanya hal-hal yang dilengkapi dan dicermati oleh kelompok kami.

\section{Hasil dan Diskusi}

Dalam upaya pengembangan ide usaha pada waroeng kopi Singgah, maka kelompok kami mencoba membuat beberapa kegiatan untuk membantu meningkatnya omset dan sebagai bentuk pengenalan produk yang dimiliki oleh waroeng kopi singgah. Adapun kegiatan yang dialakukan sebagai berikut:

\section{Rebarnding Waroeng Kopi Singgah}

Rebranding menurut pendapat (Thomas 2016) adalah sebuah praktek yang membentuk suatu citra baru yang merepresentasikan perubahan posisi dalam pola pikir para stakeholder dan membedakan identitas dengan para kompetitor lainnya. Perubahan yang akan dilakukan terkait brand image yaitu adanya perubahan pada logonya dan brand identity, pada jenis fond yang digunakan. Proses perancangan itu bertujuan membuatan suatu brand yang seragam dengan karakteristik yang ada pada waroeng kopi singgah. 

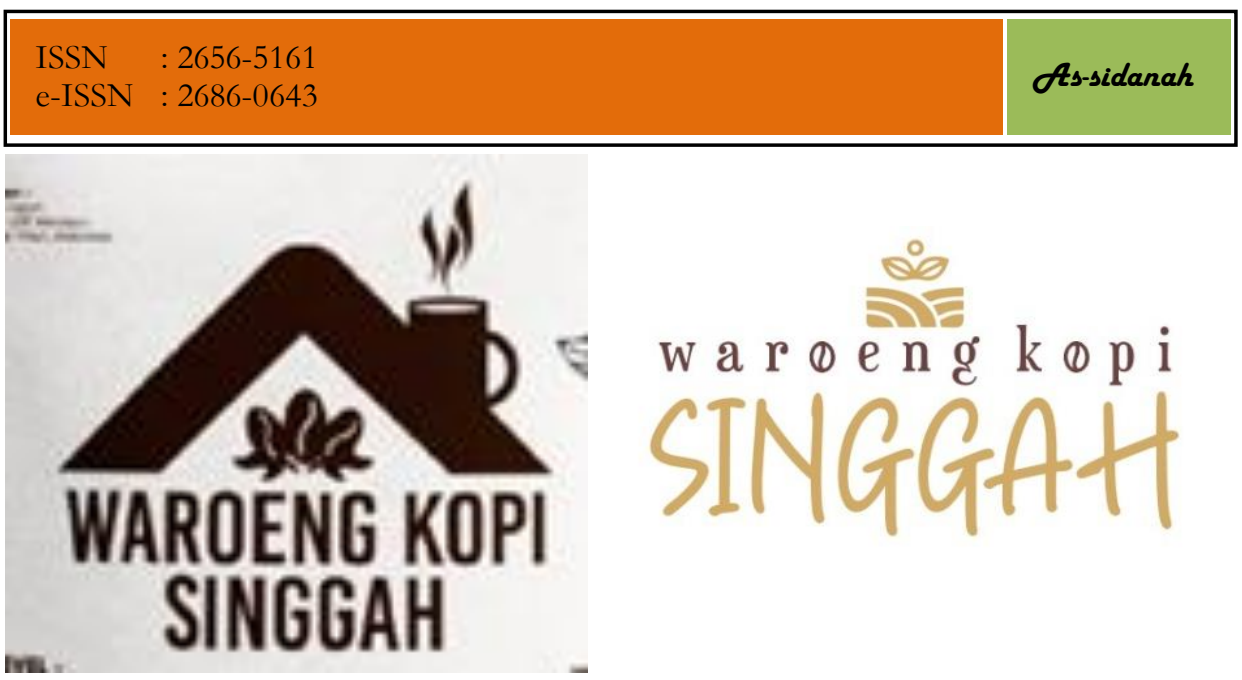

Gambar 1. Logo Lama dan Logo baru

Setelah proses pembuatan logo baru kami juga membuat varian produk untuk waroeng kopi singgah antara lain sebagai berikut :
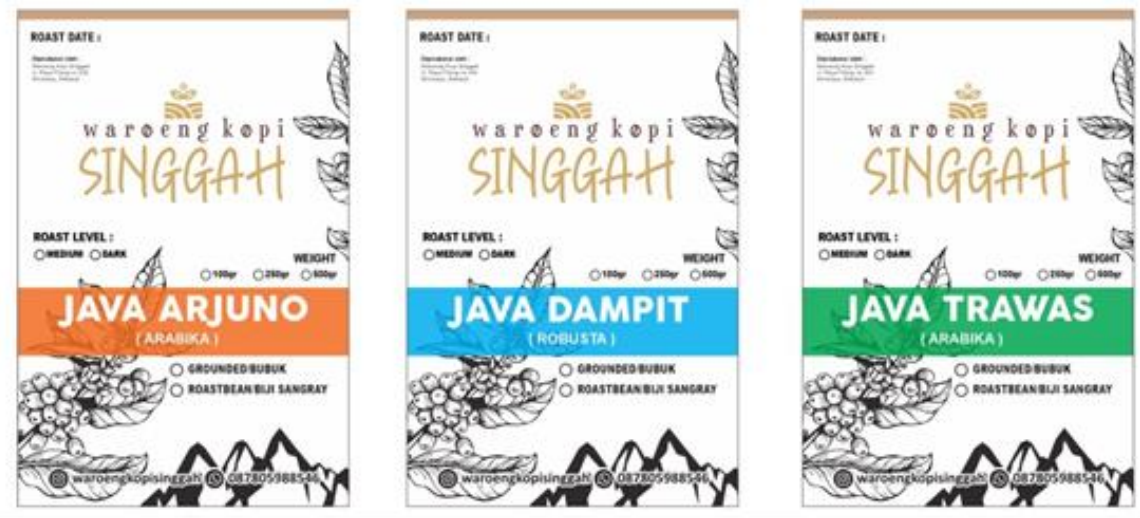

Gambar 2. Varian Produk Waroeng Kopi Singgah 


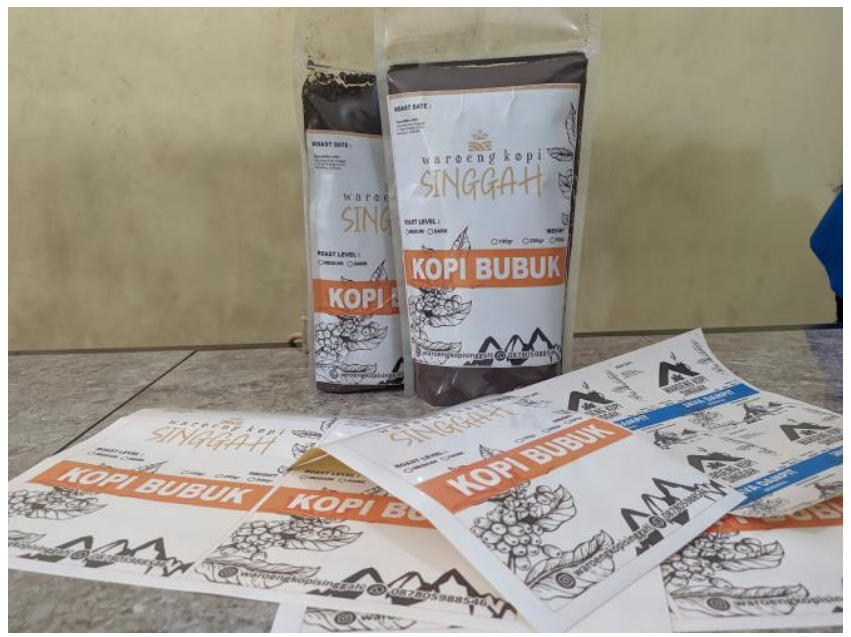

Gambar 3. Produk Waroeng Kopi Singgah

\section{Banner Waroeng Kopi Singgah}

Selain pembuatan logo baru kami juga membuatkan banner sebagai media pendukung memperkenalakan waroeng kopi singgah pada masyarakat yang ada di sekitar jalan Raya Pilang no.200, Sidoarjo. Dalam pendapat (Silvana and Damayanty 2014), kegiatan promosi yang dilakukan dengan banner memberikan suatu terpaan pesan media promosi yaitu adanya perubahan tindakan hingga menimbulkan perasaan suka dan dilanjutkan dengan tindakan menggunakan atau akan memberli produk tersebut dengan tujuan sebagai media komunikasi promosi. Pada banner yang kami buat menunjukan adanya pesan promosi waroeng kopi singgah dengan menampilkan logo, katakata, dan gambaran mengeni informasi fasilitas yang ada di waroeng kopi Singgah.

Vol. 3 No.1, April 2021
Septianti, Dkk | 8 Zurnal Pengabdian Masyarakat 


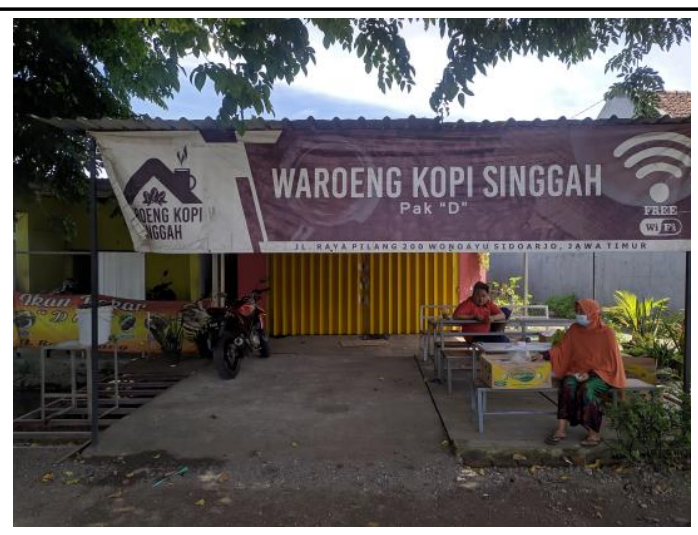

Gambar 4. Banner Waroeng Kopi Singgah

\section{Digital Marketing Waroeng Kopi Singgah}

Era digital marketing merupakan suatu peluang melalui proses teknologi digital dalam menciptakan, mengkomunikasikan, dan menyampaikan nilai-nilai yang ada pada produk kepada konsumen serta berbagai pihak yang berkepentingan lainnya (Irfani, Yeni, and Wahyuni 2020). Perkembangan teknologi digital memungkinkan para pelaku UMKM untuk memasarkan produknya secara online dan melakukan transaksi melalui sistem perbankan secara online juga. Penulis beserta owner Waroeng Kopi Singgah mencoba untuk memanfaatkan digital marketing untuk pemasaran lebih luas lagi serta peningkatan penjualan sebab masa PSBB. Berikut beberapa digital marketing yang dilakukan oleh waroeng kopi singgah : 


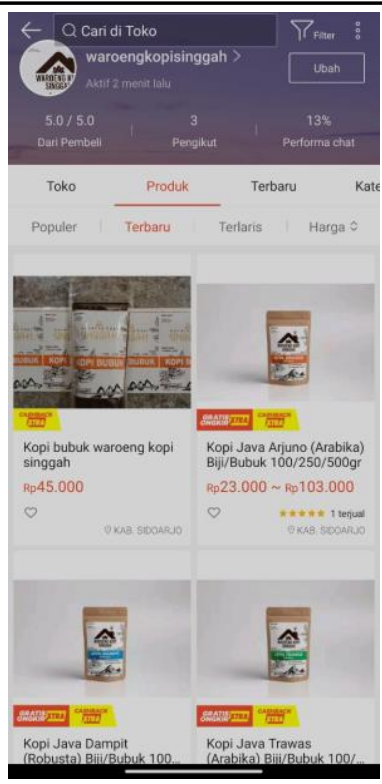

Gambar 5. Digital Marketing Menggunakan Platform Shopee

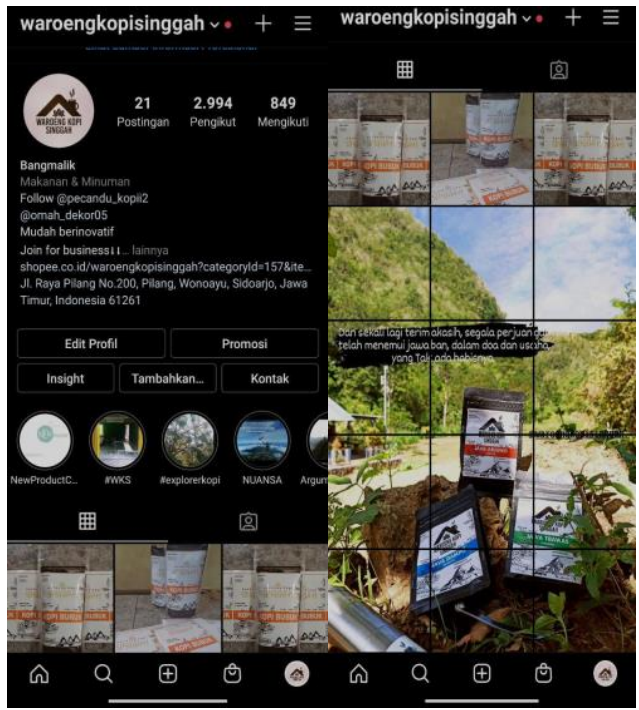

Gambar 6. Digital Marketing dengan Menggunakan Sosial Media Instagram 


\section{Kesimpulan}

Program KKN-KK yang dilaksanakan di waroeng kopi singgah di Jalan Raya Pilang no.200, Wonoayu, Sidaorjo berjalan dengan baik dan disambut dengan antusias oleh pemilik. Dalam pelaksanaan program ini dilakukan serangkaian kegiatan yaitu pembuatan Rebrading logo yang diharapakan memberikan suatu kesan yang lebih sederhana dan mengubah tipografi pada tulisan waroeng kopi singgah dengan tambahan ikon kopi pada huruf O. Selain itu juga dibuat varian produk kopi singgah dengan tiga jenis varian. Untuk mendukung penjualan dibuatkannya banner dan pemasaran melalui media online seperti facebook, Instagram, dan shopee. Melalui kegiatan yang dilakukan memberikan suatu pengembangan, pengetahuan, meningkatkan omset dengan didorong penjualan dengan media online dan membantu produk waroeng singgah dapat dikenal oleh khalayak umum.

\section{Daftar Pustaka}

Afandi, Agus. 2018. “Participatory Action Research (PAR) Metodologi

Alternatif Riset Dan Pengabdian Kepada Masyarakat

Transformatif." LPPM UIN Sunan Ampel.

Irfani, Hadi, Fitri Yeni, and Rika Wahyuni. 2020. “Pemanfaatan Digital

Marketing Sebagai Strategi Pemasaran Pada Ukm Dalam

Menghadapi." 3(3): 651-59.

Sarfiah, Sudati Nur, Hanung Eka Atmaja, and Dian Marlina Verawati. 
2019. “Umkm Sebagai Pilar Membangun Ekonomi Bangsa Msmes the Pillar for Economy." Jurnal REP (Riset Ekonomi Pembangunan) 4(2): 137-46.

Silvana, Hana, and Damayanty Damayanty. 2014. “Penggunaan X Banner Dalam Promosi Layanan Perpustakaan." Jurnal Kajian Komunikasi 2(2): 105-17.

Thomas, Jerry Fransen. 2016. “Analisa Pengaruh Rebranding Terhadap Brand Association Dengan Brand Image Sebagai Variabel Intervening Terhadap Customer Loyalty Pada PT Telkom Indihome Surabaya." Jurnal Strategi Pemasaran: 1-10. 